\title{
Prevalence of school violence and use of alcohol and other drugs in adolescents*
}

\author{
Maria Aparecida Beserra ${ }^{1}$ \\ Diene Monique Carlos² \\ Maria Neto da Cruz Leitão $0^{3}$ \\ Maria das Graças Carvalho Ferriani²
}

\begin{abstract}
Objective: to analyze the school violence suffered and practiced and its association with the use of alcohol and other drugs in adolescents between 12 and 18 years old. Method: the study sample consisted of 643 adolescents enrolled in six schools, who answered two self-administered questionnaires: "Global School-based Student Health Survey" and "Violence in School". Statistical analysis was performed using the chi-square test and the degree of association between the variables was analyzed using the prevalence ratio. Results: the prevalence of school violence suffered and practiced was $62.2 \%$ and $51.9 \%$, respectively. About $44.6 \%$ of the aggressors said they did not want to change their behavior. There was an expressive prevalence of alcohol use $(16.5 \%)$, tobacco $(15.7 \%)$ and illicit drugs $(6.8 \%)$, and drunkenness $(12.6 \%)$. There was a significant association between the violence suffered and the age group of 12 to 14 years old $(p=0.001) ;(p=0.011)$ and education level in elementary school $(p<0.001)$. In mothers with less than eight years of studies, the association was significant for the violence practiced $(p=0.002)$. Conclusion: the study contributes to the aspects involved in school violence, which can subsidize actions and policies in this area.
\end{abstract}

Descriptors: Adolescent Behavior; School Health; Violence; Street Drugs; Underage Drinking; Smoking.

\footnotetext{
* Paper extracted from doctoral dissertation, "Violence during adolescence in the school context and associated factors", presented to Escola de Enfermagem de Ribeirão Preto, Universidade de São Paulo, PAHO/WHO Collaborating Centre for Nursing Research Development, Ribeirão Preto, SP, Brazil. Supported by Fundação de Amparo à Ciência e Tecnologia do Estado de Pernambuco (FACEPE), Brazil, grant \#BCT-02294.04/11, Conselho Nacional de Desenvolvimento Científico e Tecnológico (CNPq), Brazil, grant \#140082/2013-1 and by Fundação de Amparo à Pesquisa do Estado de São Paulo (FAPESP), Brazil, grant \#2014/23620-7.

1 Universidade de Pernambuco, Faculdade de Enfermagem Nossa Senhora das Graças, Recife, PE, Brazil.

2 Universidade de São Paulo, Escola de Enfermagem de Ribeirão Preto, PAHO/WHO Collaborating Centre for Nursing Research Development, Ribeirão Preto, SP, Brazil.

${ }^{3}$ Escola Superior de Enfermagem de Coimbra, Coimbra, Portugal.
}

\section{How to cite this article}

Beserra MA, Carlos DM, Leitão MNC, Ferriani MGC. Prevalence of school violence and use of alcohol and other drugs in adolescents. Rev. Latino-Am. Enfermagem. 2019;27:e3110. [Access $+\frac{1}{+}$ ] ; Available in: DOI: http://dx.doi.org/10.1590/1518-8345.2124.3110. month day year 


\section{Introduction}

Violence is a problem that infiltrates society, threatening the healthy development of people. For these issues, it needs to be studied transversally. It is responsible for a large proportion of deaths in several countries, particularly among children, adolescents, and young adults. The exposure to violence can cause immediate physical injury that health professionals can handle. However, it can result in physical and mental health problems that are not often apparent to these professionals. Also, violence directly affects expenditures on health care; and indirectly, it generates stagnation of economic development, and increases inequities and deteriorates human capital(1).

Violence is materialized in several social spaces and, in recent years, it has been frequent in the school environment. This contradicts the role of the school. School violence is expressed in a more explicit perspective of violence, such as aggression between individuals, and in the symbolic violence that occurs through the rules, norms and cultural habits of an unequal society(2).

Adolescent development involves a progressive independence and autonomy of the family, a greater association with the pairs, the formation of the identity, and the physiological and cognitive maturation. This whirlwind of changes allow the adolescent to open new horizons and experience new behaviors, some of which involve present and future health risks, such as the use of psychoactive substances such as alcohol and illicit drugs $^{(3-4)}$. The family emerges as essential in this debate by its implication in these behaviors presented by the adolescents, besides the consideration of the ecological gaze for the understanding of the violence ${ }^{(5-7)}$. Recent literature review has brought the factors associated with the perpetuation of violence, with poor impulse control; use of alcohol or other drugs; unhealthy relationships between caregivers and children; family economic stress; exposure to community violence; increase in social inequities were factors strongly correlated with the occurrence of violence among adolescents and young people(1) $^{(1)}$

The present study lists as risk behaviors factors related to adolescents' lifestyle, such as alcohol and drug use, as well as to violent behaviors considered as predictors of the violent act. In Brazil, the analysis of these variables by the National Survey of School Health (PeNSE) conducted in 2009, using data from the Brazilian Institute of Geography and Statistics ${ }^{(8)}$, revealed that $71.4 \%$ of schoolchildren have ever tried alcoholic beverages. The use of alcohol in adolescence is a factor of exposure to health problems in adulthood, as well as significantly increasing the risk of the individual becoming an abusive consumer throughout life ${ }^{(9)}$.
According to data from PeNSE conducted in 2012, $15.9 \%$ of students suffered physical aggression in the last twelve months before conducting the research; in the PeNSE of 2015, there was an increase in the percentage of aggression to $17.3 \%^{(3-4,10)}$. Comparing the PeNSE data for 2009, 2012 and 2015, there is an increase in prevalence in almost all variables related to situations of violence involving students, as well as the severity of violence experienced by adolescents ${ }^{(11)}$. On the other hand, there is an association between the adoption of a healthy lifestyle by young people and the decrease in the relative risk of being frequently intimidated and victimized(12).

In this dimension, it is fundamental to work the behavior of adolescents in the school environment; aiming to identify the behavioral risk factors and protect these individuals are exposed. Therefore, the present study aims to identify the prevalence of violence suffered and practiced by adolescents in the school context and to analyze its association with the use of alcohol, tobacco, and other drugs. The proposed approach is shown as an emerging health issue, considering the importance that the school institution occupies in adolescents' lives, as well as the seriousness of the violent incidents that occur in this environment involving these actors. It is emphasized that adolescence constitutes a "key period" of human development, in which actions that promote a healthy adult life can be implemented(13).

\section{Methods}

This study is part of a study carried out with the objective of studying the violence suffered and/ or practiced by adolescents in the school context and the associated individual and environmental factors, in public schools in the city of Recife, state of Pernambuco, Brazil. The study was approved by the Research Ethics Committee of the University of Pernambuco, on March 20, 2012, and the study protocol was registered under CEP/UPE 10/12. Participating subjects spontaneously consented to participate in the study, which was confirmed by the signing of the Term of Assent by them and Free and Informed Consent Form by their parents or legal guardians. The Regional Education Management of Recife Norte, of the Education Department of Pernambuco, also granted the authorization to carry out this study in the State Schools. The research project was presented previously at the parents' meeting marked by the school board, in which the objectives of the study were exposed by the first author.

This is a cross-sectional study with an estimated population of 4,905 students enrolled in six state schools in a district of the municipality studied. The sample consisted of 643 adolescents, aged between 12 and 18 years old, enrolled in Elementary and Middle 
School, in 2013, and who accepted to participate in the research. Adolescents who were separated on medical leave, maternity leave or suspended; and those who did not meet the inclusion criteria were excluded. The probabilistic sampling method stratified by school was used to determine the sample size and to select the individuals, considering the estimated population size of 4,905 students enrolled in the six state schools of the studied neighborhood; the margin of error of $5.0 \%$; the $95 \%$ confidence that the margin of error is not exceeded; the expected proportion of $50.0 \%$ for each response category, which maximizes sample size. The total number of students in the sample (643) was distributed proportionally between the six selected schools and the three school shifts. All calculations for sample determination were performed through the EpiInfo program version $6.04 \mathrm{~d}$ for DOS.

The data were collected from 02/07/2013 to $06 / 05 / 2013$ by a nurse and author of this article, using two self-administered questionnaires already validated in Brazil. The first questionnaire, containing sociodemographic and behavioral questions, aims to evaluate the exposure to health risk behaviors in adolescents, being denominated Global School-Based Student Health Survey(14-15). The second questionnaire has school violence as its central theme and its objective is to evaluate the violence suffered, practiced and/or witnessed by adolescents within the school context ${ }^{(16-17)}$. The data collected were scanned in spreadsheets with double entry and the data bank was validated by a third person.

The variable outcome of the study was the occurrence of violence suffered and/or practiced in the school context, in the last two weeks that preceded the study. The type of violence was explored, who was the aggressor, who was the victim, the place where the violence occurred, how many times they were an aggressor or victim, whether they continue to attack or be attacked. The explanatory variables were selected from the Global School-Based Student Health Survey ${ }^{(14-15)}$, being age, gender, education level, residing with the mother, residing with the father, length of study of the mother, alcohol consumption and other illicit drugs (age at the beginning of consumption, number of doses of alcohol, drunkenness, where the drug was obtained).
The results were analyzed through absolute and percentage distributions. To evaluate the existence of an association between two categorical variables, the Chisquare statistical test was used and when the conditions for its use were not met, the Fisher's exact test was used. To evaluate the degree of association between the variables, the prevalence ratio (PR) and the respective confidence interval (CI) were obtained. The margin of error was $5 \%$, and the degree of association between the variables was assessed by the prevalence ratio and the respective confidence interval (CI 95.0\%). The Statistical Package for the Social Sciences (SPSS), version 21, was used to carry out all the statistical analyzes of the results.

\section{Results}

The main sociodemographic characteristics of the sample analyzed were: slightly more than half (56.5\%) of the adolescents were between 15 and 18 years old the others $(43.5 \%)$ were between 12 and 14 years old; most of them were female $(64.2 \%)$, single $(93.6 \%)$, did not work $(87.9 \%)$, and were self-considered as non-white $(82.3 \%)$, with predominance of brown/mulatto/brunette (70.6\%). Regarding the education level, just over half of the adolescents (54.1\%) attended high school; just over half $(52.3 \%)$ of the mothers of those surveyed had 8 to 11 years of study. As to housing, almost all (95.5\%) of the adolescents lived in the urban region, with their mother $(89.7 \%)$, and just over half $(56.8 \%)$ lived with their father.

The analysis of the prevalence of violence in the school revealed that most $(62.2 \%)$ of the adolescents were victim of aggression by their classmates or others in the school environment in the two weeks before the survey (Table 1). The most frequent type of aggression was verbal (54.2\%), and most of the adolescents were beaten once $(79.8 \%)$ by one person $(65.5 \%)$; however, about $12.5 \%$ of adolescents continued to be assaulted by the same people. Almost all of the aggressors were classmates (96.0\%), and the classroom was the school site where the most cited acts of violence occurred $(45.9 \%)$. Nearly half $(51.3 \%)$ of the cases of aggression were witnessed by third parties, who, for the most part, did not take any action (36.7\%) or supported the adolescent victim of violence and advised him to move away of the aggressor (27.1\%).

Table 1 - Absolute and relative distribution of the study population according to the issues related to the fact that they were victims of violence in the school*. Recife, PE, Brasil, 2013

\begin{tabular}{lcc}
\hline \multicolumn{1}{c}{ Variable } & $\mathbf{n}$ & $\%$ \\
\hline Have you ever felt victimized by peers or other people at school? $^{+}$ & 400 & 62.2 \\
Yes & 243 & 37.8 \\
No & & \\
\hline
\end{tabular}


Types of aggression suffered ${ }^{\ddagger}$

Physics

Verbal

Psychological

Patrimonial

Sexual

Other aggressions

How many times have you been beaten or persecuted?§

Once

Twice or more times

In which school did these situations occur?"

Classroom

Courtyard

Corridors and/or stairs

Dining hall

Physical Education Space

Bathroom

Other

In these situations, how many people have you been beaten?\$

One

Two

Three or more

In these situations, what people have you been assaulted?

Classmates

School workers

Are you still being beaten/persecuted by these people?§

Yes

No

Has anyone witnessed such situations?

Yes

No

What did the people who witnessed these situations do?**

Nothing

Escape /was afraid

Looked for an adult

Asked the aggressor to stop

Supported the aggressor/ Smiled at the situation

Supported you / Advised you to move away from the aggressor

Approached to see / Another attitude

*In the two weeks before the survey; +Percentage calculated in the total number of answers, $\mathrm{n}=643$; $\neq$ Considering that the same participant cited more than one answer option, the basis for calculating the percentages and not the total answers was recorded, where $n=539$; $\S$ Percentage calculated in the total answers, $n=400 ; \|, \eta, * *$ Considering that the same participant cited more than one answer option, the basis for calculating the percentages and not the total answers was recorded, being ||$n=488$, I $n=403$ and $* * n=240$ 
When questioned about having committed acts of violence in the school environment, slightly more than half $(51.9 \%)$ of adolescents said they had aggressive attitudes towards a student, teacher or any other school worker. This subgroup of aggressors of violence practiced verbal aggression (55.6\%) and physical aggression $(33.5 \%)$, generally alone $(65.0 \%)$, that is, without the help of other individuals. The main place of occurrence was within the classroom $(49.7 \%)$, followed by the courtyard (16.8\%) and corridors and/or stairs (16.8\%), against a roommate (94.37\%). Most adolescents had aggressive attitudes only once $(77.8 \%)$, and most of them had twice $(10.5 \%)$ or three or more times $(11.7 \%)$, with $6.9 \%$ of adolescents having assaulted and/or persecuted the same person more than once.

The main reasons that lead to the violent act were joking $(44.8 \%)$, irritation $(15.7 \%)$ and revenge (15.2\%). Similar to the previously report, about half (53.6\%) of the cases of aggression were witnessed by third parties, who, for the most part, did not take any action (47.4\%) or support the aggressor and/or smiled at the situation (26.3\%) Just over half of the aggressors (55.4\%) stated that they wanted to behave differently towards those who were attacked, not responding to provocations (25.6\%) or controlling themselves $(24.7 \%)$. However, $28.4 \%$ of the aggressors said they did not want to change their behavior.

The analysis of the prevalence of alcohol and other drug use (Table 2 ) showed that $16.5 \%$ of the adolescents consumed at least one dose of alcohol-containing beverage within the thirty days before the study. In this subgroup, there was predominance of adolescents who had consumed 2 doses $(23.6 \%)$ or 4 or more $(31.1 \%$ ) doses of alcoholic beverage. About half $(49.1 \%)$ of the adolescents acquired the drink consumed in a bar/ restaurant/supermarket/street vendor, and about a third $(35.8 \%)$ got it with friends. When asked if they had been drunk during their lifetime, most $(82.4 \%)$ of the adolescents answered negatively to the question, while $12.6 \%$ had already been drunk one to two times. Almost all $(93.2 \%)$ of the adolescents never consumed drugs like Ioló, glue, perfume, marijuana, crack and cocaine; and most who answered affirmatively, 5.3\% used drugs of this type one to two times.

Table 2 - Absolute and relative distribution of the study population according to the issues related to the consumption of alcohol and other illicit drugs. Recife, PE, Brasil, 2013

\begin{tabular}{|c|c|c|}
\hline Variable & $\mathbf{n}$ & $\%$ \\
\hline \multicolumn{3}{|c|}{ In the last 30 days, have you consumed at least one drink containing alcohol? ${ }^{*, \dagger}$} \\
\hline Yes & 106 & 16.5 \\
\hline No & 537 & 83.5 \\
\hline \multicolumn{3}{|l|}{ How many doses did you drink per day? t.ł $^{\dagger}$} \\
\hline Less than 1 dose & 13 & 12.3 \\
\hline One dose & 19 & 17.9 \\
\hline Two doses & 25 & 23.6 \\
\hline Three doses & 16 & 15.1 \\
\hline 4 doses or more & 33 & 31.1 \\
\hline \multicolumn{3}{|l|}{ How did you get the drink you consumed? ${ }^{+, \ddagger}$} \\
\hline Bought it in a bar/Restaurant/Supermarket/Street vendor & 52 & 49.1 \\
\hline Got it with your friends & 38 & 35.8 \\
\hline Got it in their house & 11 & 10.4 \\
\hline Stole it/Got it in some other way & 5 & 4.7 \\
\hline \multicolumn{3}{|l|}{ During your life, how many times have you been drunk?* } \\
\hline None & 530 & 82.4 \\
\hline 1 to 2 & 81 & 12.6 \\
\hline 3 or more & 32 & 5.0 \\
\hline \multicolumn{3}{|l|}{ During your life, how many times have you used illicit drugs?* } \\
\hline None & 599 & 93.2 \\
\hline 1 to 2 & 34 & 5.3 \\
\hline 3 or more & 10 & 1.6 \\
\hline
\end{tabular}

*Percentages calculated in the total answers $(n=643)$; +The questions are about the period of 30 days before the research; $\neq$ Percentages calculated in the total of affirmative answers to the first question $(n=106)$ 
The bivariate analysis of the association between the variables answer (violence suffered and violence practiced) and sociodemographic variables (Table 3 and 4) showed a significant association between the violence suffered and the age group of 12 to 14 years old $(p=0.001, R P=1.35) ;(p=0.011, P R=1.17)$ and education level in elementary school $(p<0.001, P R=1.33)$. The practice of violence decreased due to the increase in the mother's education; in mothers with less than eight years of study, the association was significant $(p=0.002$, $\mathrm{PR}=1.42)$.

Table 3 - Bivariate analysis and crude prevalence ratios of the index of violence suffered, according to sociodemographic data. Recife, PE, Brasil, 2013

\begin{tabular}{|c|c|c|c|c|c|c|}
\hline \multirow{3}{*}{ Variable } & \multicolumn{4}{|c|}{ Violence suffered } & \multirow{3}{*}{ p-value* } & \multirow{3}{*}{$\mathrm{PR}^{\dagger}\left(\mathrm{Cl}^{\ddagger}\right.$ a $\left.95 \%\right)$} \\
\hline & \multicolumn{2}{|c|}{ Yes } & \multicolumn{2}{|c|}{ No } & & \\
\hline & $\mathbf{n}$ & $\%$ & $\mathbf{n}$ & $\%$ & & \\
\hline \multicolumn{7}{|l|}{ Age group } \\
\hline 12 to 14 & 204 & 72.9 & 76 & 27.1 & $<0.001^{\S}$ & 1.35 (1.20 a 1.52$)$ \\
\hline 15 to 18 & 196 & 54.0 & 167 & 46.0 & & 1.00 \\
\hline \multicolumn{7}{|l|}{ Gender } \\
\hline Male & 158 & 68.7 & 72 & 31.3 & $0.011^{\S}$ & $1.17(1.04$ a 1.32$)$ \\
\hline Female & 242 & 58.6 & 171 & 41.4 & & 1.00 \\
\hline \multicolumn{7}{|l|}{ Marital status } \\
\hline Single & 373 & 62.0 & 229 & 38.0 & 0.610 & 1.00 \\
\hline Married/Stable union & 27 & 65.9 & 14 & 34.1 & & $1.06(0.85$ a 1.34$)$ \\
\hline \multicolumn{7}{|l|}{ Education level } \\
\hline Elementary school & 212 & 71.9 & 83 & 28.1 & $0.001^{\S}$ & $1.33(1.18$ a 1.50$)$ \\
\hline High school & 188 & 54.0 & 160 & 46.0 & & 1.00 \\
\hline \multicolumn{7}{|l|}{ Residing with } \\
\hline Parents & 210 & 63.3 & 122 & 36.7 & 0.817 & $1.10(0.81$ a 1.49$)$ \\
\hline Only with the mother & 149 & 60.8 & 96 & 39.2 & & $1.06(0.78$ a 1.44$)$ \\
\hline Only with the father & 22 & 66.7 & 11 & 33.3 & & $1.16(0.79$ a 1.69$)$ \\
\hline Other person & 19 & 57.6 & 14 & 42.4 & & 1.00 \\
\hline \multicolumn{7}{|l|}{ Education level of the mother } \\
\hline Less than 8 years & 124 & 66.7 & 62 & 33.3 & 0.324 & $1.09(0.92$ a 1.30$)$ \\
\hline 8 to 11 years & 202 & 60.1 & 134 & 39.9 & & $0.98(0.83$ a 1.16$)$ \\
\hline 12 or more & 74 & 61.2 & 47 & 38.8 & & 1.00 \\
\hline
\end{tabular}

*P-value determined by Pearson's Chi-square test; +PR - Prevalence ratio; $¥ \mathrm{CI}$ - Confidence Interval of 95\%; §Significant difference of 5.0\%

Table 4 - Bivariate analysis and crude prevalence ratios of the violence rate practiced, according to sociodemographic data. Recife, PE, Brasil, 2013

\begin{tabular}{|c|c|c|c|c|c|c|}
\hline \multirow{3}{*}{ Variable } & \multicolumn{4}{|c|}{ Violence practiced } & \multirow{3}{*}{$p$-value ${ }^{*}$} & \multirow{3}{*}{$\mathrm{PP}^{\dagger}(\mathrm{IC} \mp$ to $95 \%)$} \\
\hline & \multicolumn{2}{|c|}{ Yes } & \multicolumn{2}{|c|}{ No } & & \\
\hline & $\mathbf{n}$ & $\%$ & $\mathrm{n}$ & $\%$ & & \\
\hline \multicolumn{7}{|l|}{ Age group } \\
\hline 12 to 14 & 163 & 58.2 & 117 & 41.8 & $0.005^{\S}$ & $1.24(1.07$ a 1.43$)$ \\
\hline 15 to 18 & 171 & 47.1 & 192 & 52.9 & & 1.00 \\
\hline \multicolumn{7}{|l|}{ Gender } \\
\hline Male & 143 & 62.2 & 87 & 37.8 & $<0.001^{\S}$ & $1.34(1.16$ a 1.55$)$ \\
\hline Female & 191 & 46.2 & 222 & 53.8 & & 1.00 \\
\hline \multicolumn{7}{|l|}{ Education level } \\
\hline Elementary school & 177 & 60.0 & 118 & 40.0 & $<0.001 \S$ & $1.33(1.15$ a 1.54$)$ \\
\hline High school & 157 & 45.1 & 191 & 54.9 & & 1.00 \\
\hline
\end{tabular}




\begin{tabular}{|c|c|c|c|c|c|c|}
\hline \multirow{3}{*}{ Variable } & \multicolumn{4}{|c|}{ Violence practiced } & \multirow{3}{*}{ p-value* } & \multirow{3}{*}{$\mathrm{PP}^{\dagger}\left(\mathrm{IC} \mathrm{C}^{\ddagger}\right.$ to $\left.95 \%\right)$} \\
\hline & \multicolumn{2}{|c|}{ Yes } & \multicolumn{2}{|c|}{ No } & & \\
\hline & $\mathbf{n}$ & $\%$ & $\mathbf{n}$ & $\%$ & & \\
\hline \multicolumn{7}{|l|}{ Working } \\
\hline Yes & 39 & 50.0 & 39 & 50.0 & 0.714 & 1.00 \\
\hline No & 295 & 52.2 & 270 & 47.8 & & $1.04(0.83$ a 1.32$)$ \\
\hline \multicolumn{7}{|l|}{ Residing with } \\
\hline Parents & 174 & 52.4 & 158 & 47.6 & 0.841 & 1.00 \\
\hline Only the mother & 123 & 50.2 & 122 & 49.8 & & $0.96(0.82$ a 1.13$)$ \\
\hline Only the father & 19 & 57.6 & 14 & 42.4 & & $1.10(0.81$ a 1.50$)$ \\
\hline Other person & 18 & 54.5 & 15 & 45.5 & & $1.04(0.75$ a 1.44$)$ \\
\hline \multicolumn{7}{|c|}{ Education level of the mother } \\
\hline Less than 8 years & 116 & 62.4 & 70 & 37.6 & $0.002^{\S}$ & $1.42(1.13$ a 1.79$)$ \\
\hline 8 to 11 years & 165 & 49.1 & 171 & 50.9 & & $1.12(0.89$ a 1.41$)$ \\
\hline 12 or more & 53 & 43.8 & 68 & 56.2 & & 1.00 \\
\hline
\end{tabular}

The bivariate analysis of the association between the answer variables (alcohol, tobacco and illicit drug use) and sociodemographic variables (age and gender of adolescents, violence suffered and practiced) (Table 5) showed the existence of a significant association between the age group of adolescents with the variables: alcohol use, tobacco use and illicit drug use. It is possible to emphasize that the percentage of adolescents who practiced the acts related to these variables were about three times higher in the age group of 15 to 18 years old than in the age group of 12 to 14 years old. In this last age group, non-use of alcohol was significantly associated $(p<0.001, P R=1.00)$, as the non-use of tobacco $(p<0.001$, $P R=1.00)$ and illicit drugs $(p=0.014, P R=1.00)$. There was no significant association between the cited answer variables and adolescents' gender, violence suffered and violence practiced, despite the prevalence of women in alcohol, tobacco, and illicit drug use.

Table 5 - Bivariate analysis and crude prevalence ratios of alcohol, tobacco, and illicit drug use, according to age, gender, and violence suffered and violence practiced. Recife, PE, Brasil, 2013

\begin{tabular}{|c|c|c|c|c|c|c|}
\hline & \multicolumn{2}{|c|}{ Yes } & \multicolumn{2}{|c|}{ No } & \multirow{2}{*}{ p-value ${ }^{*}$} & \multirow{2}{*}{$\mathrm{PR}^{\dagger}\left(\mathrm{Cl}{ }^{\ddagger}\right.$ to $\left.95 \%\right)$} \\
\hline & $\mathrm{n}$ & $\%$ & $n$ & $\%$ & & \\
\hline \multicolumn{7}{|c|}{ Use alcohol } \\
\hline \multicolumn{7}{|l|}{ Age group } \\
\hline 12 to 14 & 17 & 8.3 & 187 & 91.7 & $<0.001^{\S}$ & 1.00 \\
\hline 15 to 18 & 54 & 27.6 & 142 & 72.4 & & $3.31(1.99$ a 5.50$)$ \\
\hline \multicolumn{7}{|l|}{ Gender } \\
\hline Male & 28 & 17.7 & 130 & 82.3 & 0.990 & 1.00 \\
\hline Female & 43 & 17.8 & 199 & 82.2 & & $1.00(0.65$ a 1.54$)$ \\
\hline \multicolumn{7}{|c|}{ Violence suffered } \\
\hline No & 71 & 17.8 & 329 & 82.2 & 0.267 & $1.23(0.85$ a 1.79$)$ \\
\hline Yes & 35 & 14.4 & 208 & 85.6 & & 1.00 \\
\hline \multicolumn{7}{|c|}{ Violence practiced } \\
\hline No & 58 & 17.4 & 276 & 82.6 & 0.532 & $1.12(0.79$ a 1.59$)$ \\
\hline Yes & 48 & 15.5 & 261 & 84.5 & & 1.00 \\
\hline \multicolumn{7}{|c|}{ Use of tobacco } \\
\hline \multicolumn{7}{|l|}{ Age group } \\
\hline 12 to 14 & 15 & 7.4 & 189 & 92.6 & $<0.001^{\S}$ & 1.00 \\
\hline 15 to 18 & 51 & 26.0 & 145 & 74.0 & & $3.54(2.06$ a 6.08$)$ \\
\hline
\end{tabular}




\begin{tabular}{|c|c|c|c|c|c|c|}
\hline \multirow{2}{*}{ Variable } & \multicolumn{2}{|c|}{ Yes } & \multicolumn{2}{|c|}{ No } & \multirow{2}{*}{ p-value* } & \multirow{2}{*}{$\mathrm{PR}^{\dagger}\left(\mathrm{Cl}^{\ddagger}\right.$ to $\left.95 \%\right)$} \\
\hline & $\mathrm{n}$ & $\%$ & n & $\%$ & & \\
\hline \multicolumn{7}{|l|}{ Gender } \\
\hline Male & 25 & 15.8 & 133 & 84.2 & 0.768 & 1.00 \\
\hline Female & 41 & 16.9 & 201 & 83.1 & & 1.07 (0.68 a 1.69$)$ \\
\hline \multicolumn{7}{|l|}{ Violence suffered } \\
\hline No & 66 & 16.5 & 334 & 83.5 & 0.479 & $1.15(0.79$ a 1.67$)$ \\
\hline Yes & 35 & 14.4 & 208 & 85.6 & & 1.00 \\
\hline \multicolumn{7}{|l|}{ Violence practiced } \\
\hline No & 56 & 16.8 & 278 & 83.2 & 0.443 & $1.15(0.80$ a 1.65$)$ \\
\hline Yes & 45 & 14.6 & 264 & 85.4 & & 1.00 \\
\hline \multicolumn{7}{|c|}{ Use of illicit drugs } \\
\hline \multicolumn{7}{|l|}{ Age group } \\
\hline 12 to 14 & 8 & 3.9 & 196 & 96.1 & $0.014^{\S}$ & 1.00 \\
\hline 15 to 18 & 20 & 10.2 & 176 & 89.8 & & $2.60(1.17$ a 5.77$)$ \\
\hline \multicolumn{7}{|l|}{ Gender } \\
\hline Male & 11 & 7.0 & 147 & 93.0 & 0.981 & 1.00 \\
\hline Female & 17 & 7.0 & 225 & 93.0 & & $1.01(0.49$ a 2.10$)$ \\
\hline \multicolumn{7}{|l|}{ Violence suffered } \\
\hline No & 28 & 7.0 & 372 & 93.0 & 0.840 & $1.06(0.59$ a 1.92$)$ \\
\hline Yes & 16 & 6.6 & 227 & 93.4 & & 1.00 \\
\hline \multicolumn{7}{|l|}{ Violence practiced } \\
\hline No & 25 & 7.5 & 309 & 92.5 & 0.503 & $1.22(0.68$ a 2.17$)$ \\
\hline Yes & 19 & 6.1 & 290 & 93.9 & & 1.00 \\
\hline
\end{tabular}

*P-value determined by Pearson's Chi-square test; †PR - Prevalence ratio; $¥ \mathrm{CI}$ - Confidence Interval of $95 \%$; §Significant difference of $5.0 \%$

\section{Discussion}

The prevalence of violence in the school context, in the condition in which the adolescents were victims of the aggression, was $62.2 \%$. In Brazil, the estimated prevalence is $10 \%$ to $70 \%$ and, in the international scenario, from $8 \%$ to $60 \%{ }^{(18-19)}$. In spite of the diversification of the prevalence of violence in the school context, these studies highlight common central issues: school space is not immune to the presence of violence, and adolescents' exposure to school violence is a worldwide concern that has led researchers from several areas of knowledge to investigate the occurrence of this phenomenon, such as health and education. A recent study addressing this theme identified the fragility or absence of institutional links to address school violence, given the need to think about this problem in an expanded and articulated network ${ }^{(20)}$.

The main protagonists of the violence were the classmates (96.2\%). In general, episodes of violence in the school involving only students are those that occur more frequently and have greater visibility for the different actors in this context ${ }^{(21)}$. Violent acts occurred predominantly in the classroom (45.9\%), corroborating with other studies(19-21). This space that should be protected and have a mediating figure is pointed out as a locus of violence. The literature is still incipient in the discussion of this issue, pointing out the need for a directed view at this specificity. Adolescents are incorporated into multiple contexts and each of these contexts interacts with individual characteristics in a way that exacerbates or attenuates the association between these individual characteristics and aggression or victimization. The main source of peer group formation is in the physical setting in which most children are centered $^{(22)}$.

Recent research indicates that $70-80 \%$ of victims of violence and their bullies are in the same class at school(23). Also, school violence is still associated with males, corroborating studies in the area about bullying (24-25). However, the literature has shown that the girls have attacked as much as the boys, and in a direct way ${ }^{(17)}$. Students enter the school setting with a combination of internal and interpersonal strengths and weaknesses that influence their academic success and behavioral functioning. Prevention and intervention 
efforts should take a multi-component approach to effectively addressing behavioral concerns. Programs focused on rephrasing normative beliefs while using skill-building techniques, may be best suited for improving behavior in the classroom and throughout the school(26).

Concerning the violence among adolescents in the school context, two worrying facts revealed by the present study were the high incidence $(44.6 \%)$ of aggressive adolescents who stated that they did not want to change their violent behaviors and the significant percentage (26.3\%) of adolescents who, having witnessed the aggression, supported the aggressor and laughed at the situation. Such attitudes of students who witness violence may be motivated by the desire to improve their peer status, as aggressors become popular, or out of fear, in an attitude of self-protection. The literature has pointed out the importance of looking at the spectators of violence among adolescents, who have been neglected by research and interventions; a climate of peace culture can act as a significant protective factor for violence among adolescents(27-29).

The family context emerges as preponderant in the discussion of school violence; the family is shown as the first environment of socialization and internalization of emotions and behaviors, which will be experienced in other spaces ${ }^{(6-7)}$. Although the instruments used in this study did not allow determining the number of nuclear families among the adolescents, it was identified that most of the adolescents live with the mother. This may indicate single-parent families and/or the existence of family conflicts. Literature review has brought about that family characteristics are determinant for the involvement of adolescents with bullying, especially single parenting; this fact is related to a possibility of less time for parent-child interaction and greater family stress $^{(5)}$

Another aspect related to family relationships was the significant association between violence practiced and low level of education of the mother; this issue corroborates literature in the area, "pointing out that education enhances a culture of tolerance and respect for human rights"(30). In a study about the meanings attributed to violence in the school context by teachers, they emphasized the importance of work and a directed look at the family, given the relevance of this institution to the formation and behavior of children and adolescents in other social environments( ${ }^{(31)}$. Despite this importance, the literature corroborates that family-school integration is still a challenge ${ }^{(20,31)}$.

The violence suffered by the adolescents showed association between 12 and 14 years old. The literature corroborates such findings regarding the various types of violence to which adolescents are exposed and warns that these adolescents may live and mean violence in different ways ${ }^{(27,32)}$. Therefore, it suggests the development of instruments that identify and allow more targeted interventions for these age groups.

Regarding health risk behaviors in the present study, $5.3 \%$ of adolescents used drugs and $16.5 \%$ consumed alcoholic beverages; in this last group, $12.6 \%$ of the individuals already got drunk. The PeNSE of 2012 revealed that $26.1 \%$ of $9^{\text {th }}$ grade students consumed alcoholic beverages in the last 30 days before the survey, with drunkenness reported by $21.8 \%$ of respondents ${ }^{(33)}$. The PeNSE of 2015 showed that $55.5 \%$ of the students in the $9^{\text {th }}$ grade of elementary education responded positively, experimenting with alcoholic beverages ${ }^{(10)}$. Comparing the prevalence of alcohol consumption reported in different studies, the values often differ according to the age range of the subjects.

It is important to emphasize that youth cultures are articulated with the construction and adoption of styles. Based on this understanding, alcoholic beverage has assumed a symbolic place for adolescents, and it is possible that the threshold of tolerance may be constituting a dispute, also symbolic, where those who have more tolerance to drink may be at an advantage over others, considered as more fragile. However, the greater tolerance concerns the need for progressively larger amounts of substance to produce the desired effect, increasing the risk of intoxication ${ }^{(34)}$. Also, this aspect hurts the public policies, denouncing the sale of alcoholic beverages to adolescents under 18 years old. This fact is forbidden in Brazil. While it is illegal to sell alcoholic beverages to young people under 21 , the alcohol and tobacco industries create an environment in which the consumption of these dangerous products is acceptable and, within some groups of adolescents, is expected. Many health promotion efforts to reduce health risks emphasize individual behavior change and ignore the critical role of environmental and social factors. Studies suggest that efforts to reduce alcohol consumption by young people should incorporate population-based policies for coping with excessive alcohol consumption in adults as part of a comprehensive approach to preventing alcohol-related harm ${ }^{(35)}$.

Another health risk behavior analyzed in this study was tobacco consumption. About $15 \%$ of adolescents already smoked some form of tobacco, and $61.4 \%$ of them did it for the first time when they were between 10 and 15 years old. The results of PeNSE conducted in 2015 showed that the prevalence of cigarette experimentation in adolescents in the $9^{\text {th }}$ grade of elementary school in public and private schools in Brazil was $18.49 \%$, with the highest frequency of experimentation observed in the Southern Region (24.9\%) and the lowest in the Northeast Region (14.2\%) in Brazil(10). 
Tobacco is one of the most important determinants for triggering chronic diseases. According to the World Health Organization, tobacco leads the ranking of causes of preventable deaths in the world. Also, the early onset of smoking is associated with an increased chance of using other substances harmful to health, such as alcohol and illicit drugs( ${ }^{(36)}$. In the city of Belo Horizonte, Minas Gerais, Brazil, the prevalence of smoking among adolescents and young adults was $11.7 \%$, and the main factor associated with tobacco use was excessive alcohol consumption $^{(37)}$.

The World Health Organization also highlights that the use of alcohol and tobacco by individuals under 14 is associated with increased risk of school dropout, aggression, suicide and alcohol intoxication, and the mental health, with a number of negative consequences in the short and long-term ${ }^{(36)}$. Systematic review of literature on the influence of the social network on the smoking behavior of adolescents has brought about that social isolation is related to smoking among adolescents. Also, peer selection and influence contribute to the initiation and maintenance of smoking in adolescents ${ }^{(38)}$. Thus, the importance of actions among peers is observed, essentially in the privileged school context. In addition, the look at family support is relevant. A study that analyzed predictors of smoking in young adults from smokers and non-smokers showed that low perceived levels of family social support were a critical factor for smoking among smokers and non-smokers. The association between alcohol use and depressive symptoms was also relevant ${ }^{(39)}$.

Finally, some limitations of the study are highlighted. Despite the reliability and validity of the research, the transversal design does not allow specific temporal analyzes for school violence. The study site was a specific neighborhood, which preserves particularities, limiting the generalization of the findings. The instruments used also do not allow bringing some familiar characteristics, like the number of nuclear families, preventing associations in this scope.

\section{Conclusion}

The results obtained in this study showed the high prevalence of violence involving adolescents in the school context, both as a victim and as an aggressor. The fact that this violence occurs in the classroom and colleagues witness and do not show protective actions to the victim is important aspects. The age of 12 to 14 years old and the male gender were significantly associated with the violence suffered, while the low education level of the mother was associated with the violence practiced. Also, the violence suffered or practiced showed no significant association with the use of alcohol, tobacco, and other drugs, despite the high prevalence of this behavior among adolescents. The use of other drugs was associated with the age group of 15 to 18 years old, and it was verified the sale of alcoholic beverages to children under 18 years old.

This worrying scenario leads to reflection on the effectiveness of public policy actions directed at confronting and preventing school violence among adolescents. In this sense, the present study brings significant additional knowledge to the current context of the phenomenon of violence in the school environment, which may be a base for future actions aimed at the development of healthy social skills, crucial for the development of adolescents. Also, looking at family members, educators and peers is necessary.

\section{References}

1. Sumner SA, Mercy JA, Dahlberg LL, Hillis SD, Klevens J, Houry D. Violence in the United States: Status, Challenges, and Opportunities. JAMA. [Internet]. 2015 [cited Oct 10, 2017];314(5):478-88. Available from: https://www.ncbi. nlm.nih.gov/pmc/articles/PMC4692168/.

2. Stelko-Pereira AC, Williams LCA. On the concept of school violence and the search for its definition. Temas Psicol. [Internet]. 2010 [cited Feb 8, 2017];18(1):4555. Available from: http://pepsic.bvsalud.org/pdf/tp/ v18n1/v18n1a05.pdf.

3. Barreto SM, Giatti L, Oliveira-Campos M, Andreazzi MA, Malta DC. Experimentation and use of cigarette and other tobacco products among adolescents in the Brazilian state capitals (PeNSE 2012). Rev Bras Epidemiol. [Internet]. 2014 [cited Feb 13, 2017];17(S1):62-76. Available from: http://www. scielo.br/scielo.php?script=sci_arttext\&pid=S1415790X2014000500062\&lng=pt.

4. Malta DC, Oliveira-Campos M, Prado RR, Andrade SSC, Mello FCM, Dias AJR et al. Psychoactive substance use, family context and mental health among Brazilian adolescents, National Adolescent School-based Health Survey (PeNSE 2012). Rev Bras Epidemiol. [Internet]. 2014 [cited Feb 13, 2017];17(S1):46-61. Available from: http://www.scielo.br/scielo.php?script $=$ sci_ arttext\&pid=S1415-790X2014000500046\&lng=pt.

5. Oliveira WA, Silva JL, Yoshinaga ACM, Silva MAI. Interfaces between family and school bullying: an systematic revision. Psico-USF. [Internet]. 2015 [cited Oct 10, 2017];20(1):121-32. Available from: http://www.scielo.br/scielo.php?script=sci_ arttext\&pid=S1413-82712015000100012\&lng=en\&nrm= iso.

6. Lee $\mathrm{CH}$, Song J. Functions of parental involvement and effects of school climate on bullying behaviors 
among South Korean Middle School students. J Interpers Violence. [Internet]. 2012 [cited Oct 10, 2017];27(12):2437-64. Available from: http:// journals.sagepub.com/doi/abs/10.1177/08862605114 33508?url_ver=Z39.88-2003\&rfr_id=ori: rid : crossref. org\&rfr_dat=cr_pub\%3dpubmed.

7. Voisin DR, Hong JS. A Meditational Model Linking Witnessing Intimate Partner Violence and Bullying Behaviors and Victimization Among Youth. Educ Psychol Rev [Internet]. 2012 [cited Oct 10, 2017];24(4):47998. Available from: https://doi.org/10.1007/ s10648-012-9197-8

8. Malta DC, Andreazzi MAR, Oliveira-Campos M, Andrade SSCA, Sá NNB, Moura L et al. Trend of the risk and protective factors of chronic diseases in adolescents, National Adolescent School-based Health Survey (PeNSE 2009 e 2012). Rev Bras Epidemiol. [Internet]. 2014 [cited Feb 13, 2017];17(S1):77-91. Available from: http://www.scielo.br/scielo.php?script=sci_ arttext\&pid=S1415-790X2014000500077\&lng=pt.

9. Strauch ES, Pinheiro RT, Silva RA, Horta BL. Alcohol use among adolescents: a population-based study. Rev Saúde Pública. [Internet]. 2009 [cited Feb 8, 2017]; 43(4):647-55. Available from: http://www.scielo.br/pdf/ rsp/v43n4/en_329.pdf.

10. Brasil. Instituto Brasileiro de Geografia e Estatística (IBGE). Pesquisa Nacional de Saúde do Escolar - 2015 [Internet]. Rio de Janeiro: IBGE; 2016. [cited Oct 3, 2017]. Available from: https://biblioteca.ibge.gov.br/ visualizacao/livros/liv97870.pdf.

11. Malta DC, Mascarenhas MDM, Dias AR, Prado RR, Lima $C M$, Silva MMA, et al. Situations of violence experienced by students in the state capitals and the Federal District: results from the National Adolescent School-based Health Survey (PeNSE 2012). Rev Bras Epidemiol. [Internet]. 2014 [cited Feb 8, 2017];17(S1):158-71. Available from: http://www.scielo.br/pdf/rbepid/v17s1/1415790X-rbepid-17-s1-00158.pdf.

12. Turagabeci AR, Nakamura K, Takano T. Healthy lifestyle behaviour decreasing risks of being bullied, violence and injury. PLoS One. [Internet] 2008 [cited Feb 8, 2017]; 3(2):1-11. Available from: http:// journals. plos.org/plosone/article?id=10.1371/journal. pone. 0001585 .

13. World Health Organization (WHO). Adolescent health [Internet]. Geneva: WHO; 2015 [cited Apr 30, 2015]. Available from: http://www.who.int/topics/ adolescent_health/en/.
14. World Health Organization (WHO). Global schoolbased student health survey (GSHS) [Internet]. Geneva: WHO; 2015 [cited Feb 6, 2015]. Available from: http:// www.who.int/chp/gshs/en/.

15. Legnani E, Legnani RFS, Morgenroth A. [Reproducibility and objectivity of a questionnaire on health risk behaviors in adolescents]. Coleção Pesquisa em Educação Física [Internet]. 2008 [cited May 16, 2015];7(3):351-6. Portuguese. Available from: http://www.fontouraeditora.com.br/periodico/ upload/371_1502130420.pdf.

16. Freire IP, Simão AMV, Ferreira AS. Violence among school peers in basic education - a questionnaire surveyed for the portuguese school population. Rev Port Educação. [Internet]. 2006 [cited Feb 8, 2017]; 19(2):157-83. Available from: http://www.scielo.mec. pt/pdf/rpe/v19n2/v19n2a08.pdf.

17. Prodócimo E, Silva RGC, Miguel RS, Recco KV. Meninas também agridem? Estudo sobre agressão entre escolares. Educação Foco. [Internet]. 2010 [cited May 16, 2016];15(1):59-76. Portuguese. Available from: http://www.ufjf.br/revistaedufoco/files/2011/05/ Artigo-03-15.1.pdf

18. Malta DC, Souza ER, Silva MMA, Silva CA, Andreazzi MAR, Crespo $C$, et al. Violence exposures by school children in Brazil: results from the National Adolescent School-based Health Survey (PeNSE). Ciênc Saúde Coletiva. [Internet]. 2010 [cited Feb 8, 2017];15(S2):3053-63. Available from: http://www. scielo.br/pdf/csc/v15s2/a10v15s2.pdf.

19. Centers for Disease Control and Prevention (CDC). Injury prevention \& control, 2013. [cited Jan 15, 2017]. Available from: http://www.cdc.gov/violenceprevention/ youthviolence/definitions.html.

20. Ferriani MGC, Carlos DM, Oliveira AJ, Esteves MR, Martins, JE. Institutional links to cope with school violence: an exploratory study. Esc. Anna Nery [Internet]. 2017 [cited Oct 10, 2017];21(4):e20160347. Available from: https://dx.doi.org/10.1590/2177-9465-ean-2016-0347 21. Gontijo DT, Julião CH, Kappel VB, Alves HC, Farinelli $M R$. Identification and characterization of violence in school: subsidies for prevention and confrontation actions. O Mundo da Saúde. [Internet]. 2013 [cited Feb 8, 2017];37(1):16-24. Available from: http://www. saocamilo-sp.br/pdf/mundo_saude/101/2.pdf.

22. The National Academies of Sciences, Engineering, Medicine. Preventing Bullying Through Science, Policy, and Practice. Washington, DC: The National Academies Press; 2016. [cited Out 3, 2017]. Available from: http:// 
sites.nationalacademies.org/DBASSE/BCYF/Science_on_ Bullying/index.htm

23. Salmivalli C. Bullying and the peer group: A review. Aggression and Violent Behavavior. [Internet]. 2010 [cited Feb 8, 2017];15(2):112-20. Available from: http://www.sciencedirect.com/science/article/pii/ S1359178909001050.

24. Oliveira WA, Silva MAI, Mello FCM, Porto DL, Yoshinaga ACM, Malta DC. The causes of bullying: results from the National Survey of School Health (PeNSE). Rev. Latino-Am. Enfermagem. [Internet]. 2015 [cited Sep 29, 2017];23(2):275-82. Available from: <http://www.scielo.br/scielo.php?script=sci_ arttext\&pid =S0104-11692015000200013\&lng=en\&nrm $=$ iso $>$.

25. Mello FCM, Malta DC, Prado RR, Farias MS, Alencastro LCS, Silva MAI. Bullying and associated factors in adolescents in the Southeast region according to the National School-based Health Survey. Rev Bras Epidemiol. [Internet]. 2016 [cited Sep 29, 2017];19(4):866-77. Available from: http://www.scielo. br/scielo.php?script=sci_arttext\&pid=S1415-790X2016 000400866\&lng $=$ pt\&nrm $=$ iso.

26. O'Brennan LM, Bradshaw CP, Furlong MJ. Influence of Classroom and School Climate on Teacher Perceptions of Student Problem Behavior. School Ment Health [Internet]. 2014 [cited Oct 3, 2017];6(2):125-36. Available from: http://doi.org/10.1007/s12310-014-9118-8

27. Carlos DM, Campeiz AB, Silva JL, Fernandes MID, Leitão MNC, Silva MAI, Ferriani MGC. School-based interventions for teen dating violence prevention: integrative literature review. Referencia [Internet]. 2017 [cited Oct 3, 2017];IV(14):133-46. Available from: http://www.index-f.com/referencia/2017/414133.php

28. McMahon S. Rape myth beliefs and bystander attitudes among incoming college students. J Am Coll Health. [Internet]. 2010 [cited Oct 3, 2017];59(1):311. Available from: http://dx.doi.org/10.1080/074484 81.2010 .483715

29. Moynihan MM, Banyard VL, Cares AC, Potter SJ, Williams LM, Stapleton JG. Encouraging responses in sexual and relationship violence prevention: what program effects remain 1 year later? J Interpers Violence [Internet]. 2015 [cited Oct 3, 2017];30(1):110-32. Available from: https://doi. org/10.1177/0886260514532719
30. Avanci JQ, Pinto LW, Assis SG. Treatment for cases of violence by Brazilian emergency services focusing on family relationships and life cycles. Ciênc Saúde Coletiva. [Internet]. 2017 [cited Sep 29, 2017];22(9):2825-40. Available from: http://www.scielo.br/scielo.php?script=sci_ arttext\&pid=S1413-81232017002902825\&lng=en\&nrm= iso.

31. Pedrosa SM, Gontijo DT, Souza MM, Silva MAI, Medeiros M. Violence and the school context: meanings for public education teachers. Cienc Cuidado Saúde. [Internet]. 2016 [cited Sep 29, 2017];15(3):397404. Available from: http://dx.doi.org/10.4025/ cienccuidsaude.v15i3.29815

32. Miller S, Williams J, Cutbush S, Gibbs D, ClintonSherrod M, Jones S. Evaluation of the Start Strong initiative: preventing teen dating violence and promoting healthy relationships among middle school students. ] Adolesc Health. [Internet]. 2015 [cited Sep 29, 2017];56(S2):14-9. Available from: http://dx.doi. org/10.1016/j.jadohealth.2014.11.003

33. Malta DC, Machado IE, Porto DL, Silva MMA, Freitas PC, Costa AWN, et al. Alcohol consumption among Brazilian adolescents according to the National Adolescent School-based Health Survey (PeNSE 2012). Rev Bras Epidemiol. [Internet]. 2014 [cited Feb 8, 2017];17(S)1:203-14. Available from: http:// www.scielo.br/pdf/rbepid/v17s1/1415-790X-rbepid17-s1-00203.pdf.

34. Souza SL, Ferriani MGC, Silva MAI, Gomes R, Souza TC. The representation of alcoholic beverages consumption for adolescents in a Family Health Unit. Ciênc Saúde Coletiva. [Internet]. 2010 [cited Feb 8, 2017];15(3):733-41. Available from: http://www.scielo. br/pdf/csc/v15n3/v15n3a16.pdf.

35. Xuan Z, Blanchette JG, Nelson TF, Nguyen TH, Hadland SE, Oussayef NL, et al. Youth Drinking in the United States: Relationships With Alcohol Policies and Adult Drinking. Pediatrics. [Internet]. 2015 [cited Oct 3, 2017];136(1):18-27. Available from: http://doi. org/10.1542/peds.2015-0537

36. World Health Organization. Global status report on alcohol and health 2011. [Internet]. Geneva: WHO; 2011 [cited Apr 14, 2015]. Available from: http://www.who.int/substance_abuse/publications/ global_alcohol_report/en/. 
37. Abreu MNS, Souza CF, Caiaffa WT. Smoking among adolescents and young adults in Belo Horizonte, Minas Gerais State, Brazil: the influence of family setting and social group. Cad Saúde Pública. [Internet]. 2011 [cited Feb 8, 2017];27(5):935-43. Available from: http:// www.scielo.br/pdf/csp/v27n5/11.pdf.

38. Seo D, Huang PY. Systematic Review of Social Network Analysis in Adolescent Cigarette Smoking Behavior. J Sch Health. [Internet]. 2012 [cited Dec 14, 2017]; 82(1):20-7. Available from: http://dx.doi. org/10.1111/j.1746-1561.2011.00663.x.

39. Mendel JR, Berg CJ, Windle RC, Windle M. Predicting young adulthood smoking among adolescent smokers and nonsmokers. Am J Health Behav. [Internet]. 2012 [cited Dec 14, 2017];36(4):542-54. Available from: http://dx.doi.org/10.5993/AJHB.36.4.11. Creative Commons (CC BY).

This license lets others distribute, remix, tweak, and build upon your work, even commercially, as long as they credit you for the original creation. This is the most accommodating of licenses offered. Recommended for maximum dissemination and use of licensed materials. 